China's economic cooperation related investment: An investigation of its direction and some implications for outward investment

\author{
Sumon Kumar Bhaumik* \\ Aston Business School, Aston University, \\ William Davidson Institute, University of Michigan, Ann Arbor, and \\ IZA - Institute for the Study of Labour, Bonn \\ Email: s.bhaumik@aston.ac.uk \\ Catherine Yap Co ${ }^{* *}$ \\ University of Nebraska at Omaha \\ Email: $\underline{\text { cco@mail.unomaha.edu }}$
}

September 12, 2010

\footnotetext{
Corresponding author. Economics and Strategy Group, Aston Business School, Aston University, Birmingham B4 7ET, United Kingdom; Tel: +44 (0)121 2043328; Fax: +44 (0)1212043000.

** Department of Economics, University of Nebraska at Omaha, Omaha, Nebraska 68182, USA; Tel: +1 (402) 554-2805; Fax: +1 (402) 554-3747
} 


\section{China's economic cooperation related investment: An investigation of its direction and some implications for outward investment}

\section{Introduction}

There is a fairly large literature that examines the drivers of aggregate flows of outward foreign direct investment (FDI), as well as decisions of individual firms to invest overseas. In the recent past, the focus of this literature has shifted from multinational enterprises (MNEs) based in developed countries to those that are based in emerging markets such as Brazil, China and India. ${ }^{1}$ It is now well understood that the emerging market MNEs (EMNEs) do not conform to the traditional view of MNEs. Indeed, in most cases, these firms do not possess capabilities similar to developed country MNEs and that, indeed, overseas expansion is often a means to acquire such capabilities. The high profile acquisitions of IBM's personal computer business by Lenovo of China and the Jaguar-Land Rover brands by Tata Motors of India are examples of this pursuit of capabilities.

The small but growing literature on EMNEs has examined how certain characteristics that manifest their successful survival in contexts with missing institutions and markets might be detrimental for successful overseas expansion. For example, it is now well understood that family ownership and formation of business groups in emerging markets are an optimal response to an environment of weak contract enforcement and missing (or imperfect) capital markets, respectively (Bhaumik and Gregoriou, 2010). But, as recent research suggests, family control or business group affiliation discourages overseas investment on account of factors such as weak corporate governance in such firms and reluctance to bear the cost of

\footnotetext{
${ }^{1}$ According to data from UNCTAD, outward FDI from developing countries comprised less than two percent of worldwide FDI outflows in the 1970s. By 2005-2007, the share of developing countries increased to an average rate of $14 \%$; China accounts for $10 \%$ of developing country FDI outflow (see UNCTAD's FDI on-line database).
} 
altering the style of management in an alien environment about which the emerging market firm has little information (see Bhaumik, Driffield and Pal, 2010, and the references therein).

The literature has also examined the role of alliances among firms and those between firms and overseas investors in facilitating internationalisation of emerging market firms, mostly in the context of Asian EMNEs (Bhaumik et al., 2010; Mathews, 2006; Zhan, 1995). Surprisingly, however, it has overlooked the advantages that EMNEs generally tend to derive from alliances with their own governments. Yet, there are a large number of examples that highlight the role of states in promoting business interests of national firms. The advantages enjoyed by Chinese and Indian petroleum firms in the Sakhalin oil and gas fields in Russia, as also in countries like Venezuela and Sudan, and the support provided by the Indian government for Mittal Steel (technically, a Dutch company!) when the latter experienced difficulties with its bid for Arcelor provide examples of the role that states can and do play in the internationalisation and expansion processes of EMNEs. Indeed, while the ability of states to promote domestic firms using subsidies or tax advantages has been reduced in the postWTO era, it is well understood that at least some of them still retain the ability to influence decisions in favour of their domestic firms using soft power. While state support can be important for EMNEs (or firms in general) in any industry, it is likely to prove crucial when these firms seek access to resources that are viewed as those of national importance (and thereby usually government controlled) by other countries. ${ }^{2}$

In this paper, we address this lacuna in the literature, by attempting to reconcile a state's - in this case China's - projection of soft power with factors that usually determine the extent and direction of outward FDI from emerging markets. The choice of China as focus of

\footnotetext{
${ }^{2}$ A good example of the role of the state in facilitating or hindering private transactions in such cases is that of the failed 2005 bid by the China National Offshore Oil Company Limited (CNOOC) to acquire Unocal, the US oil company. The access available to Chinese and Indian oil companies to Russia's Sakhalin oil and gas fields provides a stark contrast to CNOOC's Unocal experience.
} 
our analysis is interesting on two counts. First, there is a conjecture that the Chinese state facilitates outward FDI of Chinese MNEs, by providing crucial linkages with destination countries (Buckley et al., 2008). Further, a noticeable proportion of the overseas ventures of Chinese firms has been in resource-rich developing countries where resources are de jure or de facto under government control and not easily accessible through market transactions. ${ }^{3}$ Our proxy for the projection of soft power is the Chinese state's implicit promotion and support of Chinese contractor activities related to economic cooperation in other countries. Since these activities are mostly engineering construction projects which provide long-term benefits to foreign countries, we view them as China's investment on relationship building abroad. We find that the amount and direction of this economic cooperation investment can be well explained by factors that are used in the stylised literature to explain overseas FDI of firms. We, therefore, conclude that there is prima facie evidence that the Chinese state uses economic cooperation as a tool to facilitate overseas FDI of the Chinese MNEs (CMNEs).

The rest of the paper is structured as follows: In Section 2, we discuss the role of the Chinese state in facilitating outward FDI. The regression specification is outlined in Section 3. In Section 4, we discuss the data and the empirical strategy. The regression results and their implications are discussed in Section 5. Finally, Section 6 concludes.

\section{Outward Investment and the Chinese State}

It is generally agreed that CMNEs enjoy certain firm-specific advantages that they can leverage as they expand their operations overseas. They are able to access capital at a cost that is lower than their global rivals. In part, this is on account of access to cheap credit offered by the Chinese state-owned banks or, in the case of state-owned firms, by the state

\footnotetext{
${ }^{3}$ According to China's Ministry of Commerce, by the end of 2004, there were over 7,500 Chinese "non-trade enterprises" in the rest of the world (Hong and Sun, 2006). Most of this was in the manufacturing and natural resource sectors.
} 
itself (Antkiewicz and Whalley, 2006; Lardy, 1998; Warner, Hong and Xu, 2004). Access to inexpensive capital can also be the outcome of internal capital markets operated by Chinese conglomerates (Tsai, 2002). CMNEs are also able to leverage their relationships with the Chinese diaspora in the countries in which they invest, reducing the risk associated with such investment (Lecraw, 1977; Zhan, 1995).

During the early years of the reform process, Chinese overseas investments were dominated by large state-owned companies, and key investment decisions, including location of overseas operations, were dictated by political considerations (Hong and Sun, 2006). For example, the decision to invest in Hong Kong's infrastructure was aimed at enhancing Chinese influence in what was, at that time, British territory on which China had a claim. By 1992, the ideological debate about the direction of China's reform had been resolved, and encouragement of overseas investment by Chinese firms became an established part of the state's long term strategy. Overseas investment emerged as a tool to gain access to both technology and natural resources. High profile examples of such investments include those made in Indonesian and Algerian oil fields, South African mines, the Brazilian steel industry and the US technology sector. Outward FDI was also aimed at providing Chinese companies access to overseas markets and international brands. Haier, for example, invested in production facilities in the United States to partly bypass quotas and anti-dumping measures, while TCL gained access to the Thomson and Alcatel brands. The 1992-98 period witnessed a cautious implementation of this strategy to go global, but the strategy has been pursued vigorously since 1999. There is a growing literature on the strategic aspects of the transnationalization process of CMNEs (Sauvant, 2005; Zhang, 2005).

The determinants of the direction of Chinese outward FDI itself have been examined. Buckley et al. (2007) have demonstrated that, in keeping with expectations, outward FDI from China is positively associated with the size of the host market, its cultural proximity to 
China, and its openness to FDI. Their results are also consistent with the popular perception about the natural resource-seeking nature of Chinese outward FDI (see Deng, 2003). However, contrary to expectations, FDI is also positively correlated with a country's political risk. They explain this anomaly by alluding to the low cost of capital for CMNEs, especially those in the public sector, and the apparent lack of sophistication of risk evaluation processes of these companies.

However, while the determinants of Chinese outward FDI have been examined (see Buckley et al., 2007, and the references therein), despite the dominant role of the Chinese state in setting the agenda for strategic overseas investment, an examination of the largely state driven activities that might be correlated with outward FDI and, in some cases, form the basis for investment-for-resources (for CMNEs) swap in resource-rich countries, has remained largely unexamined. This is despite the state's dominant role in the Chinese economic landscape (Child and Tse, 2001), and despite the proximity of a large majority of the CMNEs to the Chinese state (Cheng and Ma, 2007). Indeed, the only known research that has linked the Chinese state's bilateral relations with other countries with outward FDI from China has examined the impact of the country's double taxation treaty - much more an economic incentive for firms than a proxy for the Chinese state's strategic engagement with the potential destination countries - on such FDI (Buckley et al., 2008).

As mentioned earlier, in this paper, we examine the overseas economic cooperation activities of Chinese contractors. Given these firms ties with the Chinese state, these activities arguably capture a strategic dimension in China's international engagement. In 2006, turnover from such economic cooperation activities was close to US\$ 35.7 billion, twice the magnitude of China's net outward FDI of US\$ 17.6 billion. ${ }^{4}$ A large proportion of this

\footnotetext{
${ }^{4}$ The stock of Chinese overseas FDI reached $\$ 170$ billion at the end of 2008 (see Rosen and Hanemann, 2009).
} 
investment is aimed at building infrastructure in the recipient countries, especially in developing countries. In late 2004, for example, Chinese contractors built office buildings in Luanda and repaired Angola's railway system that was mostly destroyed during the country's 27-year long civil war (Walt, 2006). In Iran, such investment has been used to develop transport-related infrastructure and dams (Walt, 2005). In both countries, soon after the initiation of "economic cooperation", Chinese oil and gas companies, who are at the forefront of Chinese outward FDI, received licences to operate large oil fields. While any causality between the economic cooperation and the aforementioned licence cannot be established without further evidence, it is easy to see that there is evidence of at least correlation between China's economic cooperation related investment on both subsequent outward FDI of Chinese companies and on their access to resources that are of national importance to other countries. Indeed, available data, reported in Figure 1, show that China's economic cooperation related investment in 2004-2006 and subsequent (2006-2008) outward FDI are positively correlated.

\section{INSERT Figure 1 about here}

\section{Model Specification}

As mentioned earlier in this paper, we examine whether factors that are used in the stylised literature to explain amount and direction of outward FDI can also explain satisfactorily the amount and direction of China's economic cooperation related investment. If they do, we would be able to conclude that there is at least prima facie evidence that this investment, which is arguably a proxy for the Chinese state's strategic projection of soft power, facilitates the outward FDI of CMNEs.

The basis for our empirical exercise is the gravity model that is widely used in empirical investigations of the determinants of bilateral international exchange (trade or FDI 
flows). ${ }^{5}$ In its most basic form, the gravity equation includes trading partners' gross domestic products, per capita gross domestic products, and physical distance from each other. ${ }^{6}$ The model has reliably explained trade and investment flows across countries, and hence its popularity. The basic gravity equation can be extended to include other "distance" variables that either enhance or impede bilateral investment flows. Accordingly, we use as the basis of our analysis a gravity model that is extended to take into account other factors such as cultural similarity and resource richness of the destination countries for the Chinese economic cooperation. Following Fan et al. (2009), we also account for potential host countries' growth prospects and macroeconomic stability. ${ }^{7}$ Additionally, we take into consideration the impact of institutional quality in potential host countries for Chinese outward FDI, an important factor influencing FDI flows (Gastanaga, Nugent and Pashamova, 1998). Our regression model, therefore, is as follows:

$$
E C I_{i}=\alpha+\Gamma^{\prime} X+\Phi^{\prime} Z+e
$$

where $X$ is a vector that includes variables that capture the stylised gravity model, $Z$ is a vector of other variables that might affect FDI flows, and $e$ is the i.i.d. error term.

The literature on gravity models suggests that the following variables should be included in $X$ :

The GDP of the ECI (and hence potentially FDI) recipient country (GDP) captures market size. In general, larger countries are expected to receive a larger volume of FDI. This

\footnotetext{
${ }^{5}$ Tinbergen (1962) and Linnemann (1966), both of whom study trade flows across countries, are among the earliest contributors to this literature. The gravity model posits that trade and investment flows between any two countries is a positive function of the economic size of the countries and an inverse function of the physical distance between them.

${ }^{6}$ For contributions using trade data, see e.g., Bandyopadhyay, Coughlin, and Wall (2008), Levinson and Taylor (2008), Co (2004), and Rauch (1999). For contributions using investment data, see e.g., Bevan and Estrin (2004), McCalman (2004), Carr, Markusen, and Maskus (2001), Smith (2001), and Ferrantino (1993).

${ }^{7}$ We thank an anonymous referee for suggesting the consideration of these two factors.
} 
would especially be true if outward FDI is market seeking, which is apparently the case with at least a part of Chinese outward FDI (Taylor, 2002; Zhang, 2003).

The per capita GDP of the ECI recipient country (GDPPC) captures its state of development. Its impact on the volume of FDI is theoretically indeterminate. On the one hand, outward FDI to developed countries facilitates access to technology or products that developing country firms are unable to develop on their own. On the other hand, there is also evidence to suggest that developing country firms tend to invest more in countries at similar stages of development, where they can leverage their experience and competitive advantages acquired in their home countries (Cross et al., 2007), and where they are better able to meet the price-quality expectations of the consumers (Lecraw, 1977) than their developed country rivals.

The geographical distance between the source and recipient countries of ECI (GEODIST) that captures the transportation cost of doing business. It is easy to see that the relationship between FDI and geographical distance is type dependent. The extent of horizontal FDI increases with geographical distance because distance increases the transactions cost of trade (Brainard, 1993; Horstman and Markusen, 1987; Markusen and Venables, 1998). By contrast, vertical FDI and distance have an inverse relationship on account of the adverse impact of transport cost on input cost (Helpman, 1984). The empirical evidence suggests that, on balance, the relationship between FDI and geographical distance between source and recipient countries is indeed inverse (Bevan and Estrin, 2004; Shatz and Venables, 2001).

In the $Z$ vector, to begin with, we control for economic fundamentals of the ECIrecipient countries. If economic cooperation related investment is intended to facilitate greater economic integration between China and the recipient countries, by way of trade and Chinese outward FDI, it should at least in part be driven by such economic fundamentals. Fan 
et al. (2009) suggest the inclusion of two factors related to potential host countries' economic track record. One factor is related to economic growth expectations (EXPGROW) while the other captures the stability of these countries economic performance (INSTAB). They argue that there are more investment opportunities in countries where expected growth is higher and where macroeconomic policies are more predictable (thus, where economic outcomes are more stable).

We then include the cultural distance between China and the potential ECI recipient country that captures the non-transportation transactions cost of doing business (CULDIST). Bartlett and Ghoshal (1989) have argued that cost of entry increases with distance while operational benefits and ability to transfer core competencies to overseas operations are inversely related to it. Similarly, Rauch (1999) suggests that the cost of doing business with countries that are culturally close is lower.

The evidence about the nature of the relationship between bilateral trade between China and potential recipient of ECI (BITRADE) that captures the extent to which the two economies are integrated, and perhaps also whether at least one of the two countries has resources that are of strategic importance to the other. ${ }^{8}$ The empirical evidence about the impact of bilateral trade on FDI flows is mixed. Egger (2001), for example, argues that, for European countries, exports and outward FDI are substitutes, while Bevan and Estrin (2004) and Liu, Wang and Wei (2001) find that exports (imports) and outward (inward) FDI are complementary.

Next, we include a measure of institutional quality (INSTQLTY), or business environment, that impact performance and hence strategic decisions of firms. It is stylised that weak institutions in the form of weak property rights (Grossman and Hart, 1986; Lee and

\footnotetext{
${ }^{8}$ It is easy to see that in the latter case, from a OLI theory point of view, there are potential gains from outward FDI from one to the other to internalise this strategic advantage (Markusen, 1995).
} 
Mansfield, 1996), and corruption (Wei, 2000) can have adverse impact on FDI flows, largely by increasing uncertainty and increasing contracting cost. However, from the Chinese perspective, institutional quality may be less important, and indeed Chinese firms may be attracted to countries with weak institutions. This is because Chinese firms "have developed sophisticated measures that help them operate despite endemic government interference and related problems." (Morck, Yeung and Zhao, 2008, p. 346). ${ }^{9}$ Indeed, this ability to deal with (or even thrive) in contexts where institutions are weak is not specific to Chinese firms. Recent research suggests that this is also true for firms from other emerging markets such as India and that therefore developing countries are preferred destinations for outward FDI from these countries (Bhaumik and Driffield, forthcoming).

Finally, we include two variables that capture the popular wisdom about Chinese strategic economic interests in other countries. First, we include a measure for the natural resource endowment of the recipient country $(N R)$. As we have already noted, part of the Chinese "go global" strategy is to gain access to scarce natural resources. There is evidence to suggest that a significant proportion of outward FDI by Chinese companies, led by stateowned firms, is in natural resources (Cai, 1999; Zhan, 1995; Morck et al., 2008: Table 3). There is also evidence to suggest that this activity has been actively supported by the Chinese state (Jubany and Poon, 2006). Second, we also include a measure of political rights in the recipient country (POLRIGHT). This not only accounts for the popular perception that China's strategic interests include developing business relationships with resource rich developing countries with autocratic regimes, it is also consistent with the more general empirical evidence (Mathur and Singh, 2007; Schulz, 2007). ${ }^{10}$

\footnotetext{
${ }^{9}$ Morck et al. (2008, p. 338) report that, "as of the end of 2006 Asia, Latin America, and Africa account for 63.9, 26.3 and 3.4\% of the [Chinese] FDI stock, respectively, and the shares for North America and Europe are each below 3\%."

${ }^{10}$ This may not be as counter-intuitive as it may seem at first glance. Note that the cost of negotiating a contract is likely to be lower in an environment where there is a unique centre of political power
} 
Our regression specification, therefore, is as follows:

$$
\begin{aligned}
E C I_{i}= & \alpha+\gamma_{1} \text { GDP }_{i}+\gamma_{2} \text { GDPPC }_{i}+\gamma_{3} \text { GEODIST }_{i}+\phi_{1} \text { EXPGROW }_{i} \\
& +\phi_{2} \text { INSTAB }_{i}+\phi_{3} \text { CULDIST }_{i}+\phi_{4} \text { BITRADE }_{i}+\phi_{5} \text { INSTQLTY }_{i}+\phi_{6} N_{i} \\
& +\phi_{7} \text { POLRIGHT }_{i}+e_{i}
\end{aligned}
$$

where $i$ is the index for the $E C I$ recipient countries. We also experiment with interactions between $N R$ and the measures of institutional quality and political rights. The purpose of this experiment is to examine whether the Chinese state interact differently with resource rich countries that have different levels of institutional quality and political rights - Australia, Russia and Nigeria, for example - or, conversely, whether the way in which the Chinese state interact with a country with a given level of institutional quality or political right depends on whether or not that country is resource rich (see Schulz, 2007).

If indeed economic cooperation related investment manifests the Chinese state's strategic interests and projection of soft power in a way that subsequently facilitates outward FDI of CMNEs, we should observe two things. First, this specification, which is used in the stylised literature to explain quantity and direction of FDI flows, should also explain the quantity and direction of ECI reasonably well. Second, the qualitative impact of these explanatory variables on Chinese economic cooperation related investment should be consistent with those observed in the stylised FDI literature. We shall revisit these issues later in the paper.

\section{Data and Empirical Strategy}

than in an environment where multiple agents with diverse interests wield veto powers. Mathur and Singh (2007) argue that "democratizing developing economies are often unable to push through the kind of economic reforms that investors desire, due to the presence of competing political interests" (p. 5). This is also consistent with evidence from the sub-national level in India which suggests that firm entry in a state is inversely related to the extent of democracy in it (Bhaumik, Gangopadhyay and Krishnan, 2009). 
The data on China's economic cooperation related investment - the dependent variable in our regression model - are obtained from various editions of China Statistical Yearbook. ${ }^{11}$ These are annual turnover measured in (millions of) US dollars from foreign contracted projects such as construction of dams, roads and railways.

The data for the explanatory variables in equation (2) are collected from a number of sources. Data on GDP and per capita GDP, measured in constant 2000 international dollars, are obtained from the 2005 version of the World Development Indicators that are released annually by the World Bank. Data on bilateral trade between China and each of the recipient countries are obtained from the aforementioned Yearbooks.

Following Fan et al. (2009), we measure expected growth rate for period $t$ as the average of per capita real GDP growth rates for $t-1, t-2, t-3, t-4$ and $t-5$. The authors also suggest that the standard deviation of per capita real GDP growth rates for these five years measures the predictability of each country's macroeconomic policies, and hence their economic performance. $^{12}$

Measures of geographical and cultural distance are from the Centre d'Etudes Prospectives et d'Informations Internationales (CEPII). The measure of geographical distance (in kilometers) is based on the great circle formula using the latitudes and longitudes of the most important cities in the countries. ${ }^{13}$ Following Rauch (1999), our proxy for cultural

\footnotetext{
${ }^{11}$ For detailed descriptions of these data, see p. 758 of China National Bureau of Statistics, 2007, China Statistical Yearbook 2007, Beijing: China Statistics Press. Or Statistical System of Foreign Contracted Project, Labor Service Cooperation and Design Consultation Operation issued by the Ministry of Commerce, December 30, 2004.

${ }^{12}$ For three countries (Bahrain, Oman and Zimbabwe), for the 2004-06 period, we averaged over four years due to data availability.

${ }^{13}$ This measures as-the-crow-flies distance, see Mayer and Zignano (2006) for details. It is common practice to use as-the-crow-fly distance between each partner's capitals; since CEPII's distance data capture other important cities, it is a superior measure.
} 
distance is commonality of language; it is a dichotomous variable equal to one if a language is spoken by at least $9 \%$ of the population in both China and the ECI recipient country.

In keeping with the literature (see Meyer, Estrin, Bhaumik and Peng, 2009), we use as proxies of institutional quality indices generated by the Heritage Foundation. Since indices measuring various aspects of institutional quality are highly correlated, we choose the corruption index as our measure of this quality. This is consistent with the large literature on the impact of corruption on FDI. The index has a range of zero through 100, and a high measure on this 100-point scale indicates low incidence of corruption.

Information about the natural resource endowments of the recipient countries for Chinese investment, measured as the shares of energy and non-energy minerals in their exports, were also obtained from the World Development Indicators. These are the best available proxies for the relative importance of resources in a country's economy. Ideally, we would have preferred to use energy and non-energy shares in the GDP, but these data are not readily available. ${ }^{14}$

Finally, also in keeping with the stylised literature, we use as our measure of the quality of political rights in the recipient countries the index reported by Freedom House. It is a 7-point index, with a score of 1 indicating the highest level of political freedom.

Since data for developing countries - destination for a significant proportion of Chinese economic cooperation related investment - are not always available for all the years, we have sometimes had to substitute missing values with available values of the corresponding variables going back one or two years. For example, if data for energy exports for 2000 are not available for a country, we have substituted it with the energy export data for 1999 or, if data for 1999 are unavailable as well, with data for 1998. When working with

\footnotetext{
${ }^{14}$ We have also estimated regression models that use as the measure of resource richness the combined share of fuels and minerals in total exports, but since the results are very similar to those reported in the next section, we do not report them in this paper.
} 
developing country data, such imputation of value of missing values is not uncommon in the literature (see Meyer et al. 2009), and helps minimise loss of observations on account of missing data. Imputation is mostly done for fuel and mineral exports, and no more than $6 \%$ of these data are imputed in the 1998-2000 and 2001-2003 periods. However, availability of these data in 2003 is comparatively low so the extent of imputation for 2004-2006 is higher at $17 \%$ for fuels and $14 \%$ for minerals. Importantly, a comparison of the 2003 data with the 2001 and 2002 data show that the latter are within 3 percentage points of the 2003 value for about $90 \%$ of all countries with comparable data for these years. Hence, we conclude that the exercise involving imputation could not have affected our estimation significantly.

As evident from the above discussion, we have data for nine years: 1998-2006, for up to 133 destinations of Chinese economic cooperation related investment. We aggregate the data into three periods - 1998-2000, 2001-2003 and 2004-2006 - and use period aggregates for the investment variable as the dependent variable in our regression analysis. ${ }^{15}$ This technique, variations of which are widely used in the economics literature (see Barro, 1991; Bhaumik, Gangopadhyay and Krishnan, 2009), ensures that our results are not affected by year-specific idiosyncratic spikes in the investment data. We did not pool the data for all nine years together because such pooling would have obscured the changing nature of Chinese economic cooperation related investment, if indeed there were a change in the determinants of ECI over time. While we did not have any reason to believe a priori that these determinants would be different across the different time periods, our approach allows the data to suggest whether there were actually any change in the determinants of such investment over time. To verify the robustness of our results, we later supplement this by pooling together the data for all nine years, and estimating equation (2) using panel data technique.

\footnotetext{
${ }^{15}$ For any one of these three time periods, we have data on between 92 and 118 destinations for economic cooperation related investment.
} 
Also, to eliminate the problem of endogeneity, we use lagged values of the explanatory variables. For example, we explain the variation in the 1998-2000 aggregates of economic cooperation related investment using 1997 values of the independent variables. And, data for 1993 to 1997 are used to obtain expected growth and the standard deviation of per capita GDP for the same time period.

The distributions of the natural log of ECI (LECI) for the three periods appear in Figure 2. A right-ward shift in the distribution is quite evident, indicative of an increase in Chinese economic cooperation investment across countries over time. Before reporting the full descriptive statistics for ECI and its regressors, we also highlight the relationship between $E C I$ and some recipient country characteristics that have been the source of many discussions in popular discourses about Chinese overseas investment.

In Figure 3, we report the relationship between ECI and the natural resource richness of the recipient countries, as captured by the shares of energy (FUEL) and non-energy minerals (MINERAL) in their exports. In Figure 4, we report the relationship between ECI and the institutional quality (CORRFREE) of and the political freedom (POLRIGHT) in the recipient countries. Figure 3 suggests that if one considers only countries that are rich in natural resources, with energy or non-energy minerals accounting for more than $30 \%$ of their exports, a mild positive relationship may be observed between $E C I$ and natural resource richness of the recipient countries. However, there is a large variation in ECI in countries for whom the natural resource intensiveness of exports is less than $20 \%$. Overall, if one ignores the outliers in the top right and bottom left quadrants of the scatter diagrams, there is little sign of any pattern between $E C I$ and these recipient country characteristics. Similarly, Figure 4 is not indicative of any definitive patterns between $E C I$ and corruption and political rights in these recipient countries.

INSERT Figures 2-4 about here 
The descriptive statistics for ECI and our regressors are reported in Table 1, separately for the three aforementioned time periods. ${ }^{16}$ Some interesting things are immediately obvious from these statistics. First, while the average recipient country of China's ECI is quite developed, with a per capita income of $\$ 9,000-10,000$ in all the three periods, there is a huge variation in their state of development. Hence, if indeed economic cooperation related investment is a strategic tool for projection of China's soft power and strategic interests, it is targeted at a wide range of countries, developed and developing. Second, the average investment recipient country is quite far from China, with their capital cities separated by about 9,000 kilometres, on average. This is consistent with the popular perception about China's increasing strategic interests in other continents like Africa and Latin America. Third, to the extent that such investment is aimed at ensuring Chinese companies' control of natural resources, fuel (i.e., oil and gas) is much more important than other natural resources. The share of fuel in the exports of the average investment recipient country is about $15 \%$ or higher. However, this share declined from a peak of $19.5 \%$ for the 2001-03 period to $14.6 \%$ for the $2004-06$ period, indicating that China may not be as focussed on oil and gas as it used to be earlier this decade. Finally, while the Chinese state is not averse to doing business with corrupt countries, contrary to popular perceptions, it does not have a cosy relationship with dictatorial and tyrannical regimes. While the average recipient country scores 43 on the 100-point corruption scale (100 being least corrupt), it scores 3-3.3 on the 7-point political rights scale ( 1 being the best). Indeed, while the corruption score of the average country has remained steady at around 43 over time, the political rights score has improved from 3.29 in $1998-2000$ to 3.02 in 2004-06.

\section{INSERT Table 1 about here}

\footnotetext{
${ }^{16}$ For the most part, the values of the variance inflation factors (VIFs) for the specification are less than 7 , indicating that the multicollinearity problem in the specification of equation (2) is not significant.
} 


\section{Discussion of Regression Results}

The regression estimates for equation (2), augmented by the interaction terms, are reported in Table 2, as are the robust standard errors within parentheses. We report the estimates of six models. Models (1) - (3) use as the measure for resource richness the share of the fuel (energy) exports in total exports of the countries that are the destinations of China's economic cooperation related investment, while models (4) - (6) use the share of ores and minerals (non-energy mining) exports in total exports of these countries. Note that our regression coefficients for the interaction terms are largely insignificant; and, even when they are statistically significant, they are very small and not economically meaningful. Hence, in the rest of this section, we shall not discuss them any further.

\section{INSERT Table 2 about here}

The F-statistics for all six models are significant at the $1 \%$ level, and the R-squared values range between 0.41 and 0.48 , indicating that the regression models fit the data reasonably well. ${ }^{17}$ To recapitulate, one aim of our exercise was to see whether a specification that is used in the literature to explain the magnitude and direction of FDI flows also explains well the magnitude and direction of Chinese economic cooperation related investment. If it did - which seems to be the case - we could infer that an important use of such investment, a tool to promote Chinese strategic interests overseas, is to facilitate outward FDI by Chinese companies. In light of the goodness of fit of our models to the inter-country variation in the flow of such investment, it would be reasonable to make that inference. Further, we should note that the specification worked better for the 1998-2000 and 2001-03 periods than for the 2004-06 period, at least when fuel is used as the proxy for natural resources, perhaps

\footnotetext{
${ }^{17}$ For the sake of comparison, the models estimated by Buckley et al. (2007), which use a similar framework to explain the direction of Chinese outward FDI, provide adjusted R-square values of 0.36-0.67.
} 
indicating that the Chinese state's economic cooperation related investment was a much more important tool for facilitating outward FDI during the early years of internationalisation by Chinese companies. This is perfectly consistent with the existing literature which suggests that EMNEs require more help during their early stage of internationalisation.

Next, we should discuss whether the stylised specification explains inter-recipient country variation in economic cooperation related investment in a way that is qualitatively consistent with the stylised FDI literature. For example, if a country with a higher aggregate GDP receives a larger quantity of such investment, it would be consistent with the stylised result that larger economies receive more FDI. The consistency of our results with the stylised FDI literature would provide further evidence, albeit indirect, that Chinese economic cooperation related investment is a strategic tool to facilitate the outward FDI of CMNEs.

Before embarking on that discussion, let us first summarise our results:

(i) The (log of) GDP of a country had the expected positive impact on China's economic cooperation related investment in that country only in the 2001-2003 period, and this coefficient is significant only at the $5 \%$ level.

(ii) Chinese economic cooperation related investment increases sharply with a decline in the level of development of a country, the state of development being inversely related to the GDP per capita. This is hardly surprising; developing countries would be the natural destination of these investments which primarily involve construction projects.

(iii) Ceteris paribus, Chinese economic cooperation related investment is higher for countries that are culturally closer to China.

(iv) Such investment is higher in countries with which China has significant trading relationship. Interestingly, this is true only several years (2004-2006 period regression) after China's accession to the WTO. 
(v) There is some support for the hypothesis that economic cooperation related investment would be higher in countries where the business environment or institutional quality is good. The level of investment is positively associated with the extent of freedom from corruption. However, the strength of the relationship is weak, suggesting that corruption in a country, or institutional quality in general, may not be a strong deterrent for the Chinese state's desire to do business with that country.

(vi) There is some support for the hypothesis that China's economic cooperation related investment would be higher for resource rich countries. But the correlation between the extent of a country's resource richness and Chinese investment is not economically significant (i.e., the regression coefficients have small magnitudes). Further, while such investment was statistically related to a country's energy resources up to 2003, during the 2004-2006 period investment was affected by non-energy resources alone.

(vii) There is statistical and economically meaningful support for the hypothesis that the economic cooperation related investment is higher for countries where political rights are weak for data in the 1998-2000 and 2004-2006 periods. ${ }^{18}$ However, this result is not robust to the choice of our proxy for the recipient countries' resource richness. The estimated coefficients are statistically significant if our proxy for resource richness for a country is the proportion of non-energy minerals in its exports. This could be a reflection of China's investment in African countries that are, on average, much richer in non-energy minerals than in fossil fuel, and hence whose impact on the political rights coefficient is larger in the "mineral" specification.

\footnotetext{
${ }^{18}$ Recount that our measure of political rights is such that a higher measure is associated with lower political rights.
} 
To check the robustness of our results, we also estimate the model using random effects panel regression. ${ }^{19}$ The estimates are reported in Table 3 . The Wald $\chi^{2}$ statistics indicate that both models have significant explanatory power with R-squared values (both within- and between-countries) of around 0.40. Breusch-Pagan Lagrangian multiplier tests indicate the appropriateness of the random effects panel model versus pooled regression. The coefficient estimates confirm our previous findings that economic fundamentals matter. Consistently, we find that Chinese economic cooperation investments are directed more to countries with lower per capita income, and to countries with which China has significant trading relationships. In addition, such investment is higher in countries that are energy rich and where the cost of doing business is lower on account of cultural similarity. There is once again some evidence that institutional quality (i.e., freedom from corruption) matters; in particular, economic cooperation investments are larger in countries with less perceived corruption. Once again, in the "mineral" specification, there is support for the hypothesis that China might not be averse to dealing with countries with weak political rights. But the statistical significance of this result is weaker than those reported in Table 2; it is significant only at the $10 \%$ level.

In Section 3 of this paper, we had discussed the stylised nature of the impact of our explanatory variables on FDI flows and had speculated about the likely impact of these variables on the magnitude and direction of Chinese economic cooperation related investment flows, under the assumption of complementarity between the China's ECI and the outward FDI of the CMNEs, for which there is prima facie evidence. Our results suggest that the hypothesis of the aforementioned complementarity is difficult to reject. Indeed, our

\footnotetext{
${ }^{19}$ Random effects panel regression is used because two of our regressors (physical and cultural distance) are time invariant. Fixed effects panel regression requires within-country variation over time. We should note that one limitation of the random effects model is that if the country effects are correlated with any of the other regressors, then the random effects estimates are biased and inconsistent.
} 
explanatory variables have very similar impact on China's economic cooperation related investment as on Chinese outward FDI, the latter documented elsewhere in the literature (see Buckley et al., 2008); ECI is determined largely by economic fundamentals and resource availability. While causality is far from established, we are able to make the reasonable claim that China's economic cooperation related investment is at least partly aimed at facilitating the outward FDI of the country's MNEs. We discuss the implications of this complementarity in the concluding section.

\section{Conclusion}

With implicit government support, Chinese firms undertake large scale contract projects in a number of countries under the auspices of economic cooperation. While there are suggestions that these activities is an extension of China's soft power aimed at facilitating Chinese FDI in those countries, often for access to natural resources, there is no systematic analysis of this in the literature. In this paper, our working hypothesis is that China's ECI is used to facilitate outward FDI, especially to countries that are rich in natural resources. Hence, we use as the basis for our empirical exercise the gravity model that is used in the stylised literature to examine the direction of investment flows. In our empirical specification, we also control for institutional quality and political characteristics of the investment recipient countries, to account for the popular wisdom that the Chinese state (and firms) often does business with countries where political rights and institutional quality are weak.

Our results suggest that the pattern of investment is indeed explained well by factors that are used in the stylised literature to explain directional patterns of outward FDI, namely, economic fundamentals and resource richness of the recipient countries. The impact of economic fundamentals is economically much more meaningful than the resource richness of the investment recipient countries. The results also demonstrate that, contrary to popular 
perception, China's economic cooperation related investment is more likely to flow to countries with low levels of corruption which is correlated with institutional quality in general. There is weak support, if any, for the hypotheses that China favours doing business with countries where political rights are limited.

Aside from the political economic implications for Chinese economic cooperation related investment and the country's outward FDI, our results have significant implications for EMNEs in general: in order to successfully internationalise using outward FDI, it may be important (even imperative) for aspiring firms to maintain linkages with their respective governments. Since relationships are developed over time, older and well established firms are more likely to be able to leverage the state's help than relatively new firms. Further, an alliance between the state and firms aspiring to internationalise might require a greater alignment of their interests, such that government support is more likely to be provided to firms that operate in industries like natural gas and oil that involve the strategic interests of the state. Finally, such alliance might be useful only if the government itself has sufficient soft or hard power to facilitate the internationalisation process of domestic firms. To the extent that the state's support is critical in the internationalisation process, therefore, firms from relatively weak countries that cannot project power but may be part of regional alliances are more likely to internationalise regionally, while firms from larger and more powerful emerging markets like the BRIC countries are more likely to internationalise globally. 


\section{References}

Ankiewicz, A., \& Whalley, J. 2006. Recent Chinese buyout activities and the implications for global architecture. Working paper no. 12072, National Bureau of Economic Research, Cambridge, MA.

Bandyopadhyay, S., Coughlin, C.C., \& Wall, H.J. (2008). Ethnic networks and US exports. Review of International Economics, 16: 199-213.

Barro, R.J. 1991. Economic growth in a cross section of countries. Quarterly Journal of Economics, 106(2): 407-443.

Bartlett, C.A., \& Ghoshal, S. 1989. Managing across borders: The transnational solution. Cambridge, MA: Harvard Business School Press.

Bevan, A.A., \& Estrin, S. 2004. The determinants of foreign direct investment into European transition economies. Journal of Comparative Economics, 32(4): 775-787.

Bhaumik, S.K. \& Driffield, N., forthcoming. Direction of outward FDI of EMNEs: Evidence from the Indian pharmaceutical sector. Thunderbird International Business Review.

Bhaumik, S.K., Driffield, N. \& Pal, S. 2010. Does ownership of emerging market firms affect their outward FDI? The case of Indian automotive and pharmaceutical sectors. Journal of International Business Studies, 41: 437-450.

Bhaumik, S.K., Gangopadhyay, S. \& Krishnan, S. 2009. Reforms and entry: Evidence from the Indian manufacturing sector. Review of Development Economics, 13(4): 658-672.

Bhaumik, S.K. \& Gregoriou, A. 2010. 'Family' ownership, tunnelling and earnings management: A review of the literature. Journal of Economic Surveys, 24(4): 705730 .

Brainard, S.L. 1997. An empirical assessment of the proximity-concentration trade-off between multinational sales and trade. American Economic Review, 87(4): 520-544.

Buckley, P.J., Clegg, L.J., Cross A.R., Liu, X., Voss, H. \& Zheng, P. 2007. The determinants of Chinese outward foreign direct investment. Journal of International Business Studies, 38(4): 499-518.

Buckley, P.J., Clegg, L.J., Cross A.R., Voss, H., Rhodes, M., \& Zheng, P. 2008. Explaining China's outward FDI: An institutional perspective. In K.P. Sauvant, K. Mendoza, K. $\&$ I. Ince (Eds), The rise of transnational corporations from emerging markets: Threat or opportunity?: 104-157. Cheltenham: Edward Elgar Publishers.

Cai, K.G. 1999. Outward foreign direct investment: A novel dimension of China's integration into the regional and global economy. China Quarterly, 160(December): 856-880.

Carr, D.L., Markusen, J.R., \& Maskus, K. 2001. Estimating the knowledge-capital model of the multinational enterprise. American Economic Review, 91(3): 693-708.

Cheng, L.K., \& Ma, Z. 2007. China's outward FDI: Past and future. Mimeo, National Bureau of Economic Research, Cambridge, MA, http://www.nber.org/books_in_progress/china07/cwt07/cheng.pdf.

Child, J., \& Tse, T.K. 2001. China's transition and its implications for international business. Journal of International Business Studies, 32(1): 5-21.

Co, C.Y. 2007. U.S. exports of knowledge-intensive services and importing country characteristics. Review of International Economics, 15: 890-904.

Cross, A.R., Buckley, P., Clegg, H., Voss, M.R., Zheng, P., \& Lui, X. 2007. An econometric investigation of Chinese ODI, In J.H. Dunning, \& T-M. Lin (Eds), Multinational enterprises and emerging challenges of the $21^{\text {st }}$ century: 55-85. Cheltenham: Edward Elgar.

Deng, P. 2003. Foreign direct investment by transnationals from emerging countries: The case of China. Leadership and Organizational Studies, 10(2): 113-124. 
Egger, P. 2001. European exports and outward foreign direct investment: A dynamic panel data approach. The Review of World Economics, 137(3): 427-449.

Fan, J.P.H., Morck, R., Xu, L.C., \& Yeung, B. 2007. Does 'good government' draw foreign capital? Explaining China's exceptional foreign direct investment inflow. World Bank Policy Research Working Paper 4206.

Fan, J.P.H., Morck, R., Xu, L.C., \& Yeung, B. 2009. Institutions and foreign direct investment: China versus the rest of the world. World Development, 37(4): 852-865.

Ferrantino, M. 1993. The effect of intellectual property rights on international trade and investment. Review of World Economics/Weltwirtschaftliches Archiv, 129: 300-331.

Gastanaga, V., Nugent, J.B. \& Pashamova, B. 1998. Host country reforms and FDI inflows: How much difference do they make? World Development, 26(7): 1299-1314.

Grossman, S.J., \& Hart, O.D. 1986. The costs and benefits of ownership: A theory of vertical and lateral integration. Journal of Political Economy, 94(4): 691-719.

Helpman, E. 1984. A simple theory of international trade with multinational corporations. Journal of Political Economy, 92(3): 451-471.

Hong, E., \& Sun, L. 2006. Dynamics of internationalization and outward investment: Chinese corporations' strategies. The China Quarterly, 187(December): 610-634.

Horstman, I., \& Markusen, J.R. 1987. Strategic investments and the development of multinationals. International Economic Review, 28(1): 109-121.

Jubany, F., \& Poon, D. 2006. Recent Chinese engagement in Latin America and the Caribbean: A Canadian perspective. Research report, Canadian Foundation for the Americas, Ottawa.

Lardy, N.R. 1998. China's unfinished economic revolution. Brookings Institution, Washington, DC.

Lecraw, D.J. 1977. Direct investment by firms from less developed countries. Oxford Economic Papers, 29(3): 442-457.

Lee, J-Y., \& Mansfield, E. 1996. Intellectual property protection and US foreign direct investment. Review of Economics and Statistics, 78(2): 181-186.

Levinson, A., \& Taylor, M.S. 2008. Unmasking the pollution haven effect. International Economic Review, 49: 223-254.

Linnemann, H. 1966. An econometric study of international trade flows. Amsterdam: NorthHolland.

Liu, X., Wang, C., \& Wei, Y. 2001. Causal links between foreign direct investment and trade in China. China Economic Review, 12(2-3): 190-202.

Markusen, J.R., \& Venables, A. 1998. Multinational firms and the new trade theory. Journal of International Economics, 46(2): 183-203.

Markusen, J.R. 1995. The boundaries of multinational enterprises and the theory of international trade. Journal of Economic Perspectives, 9(2): 169-189.

Mathews, J.A. 2006. Dragon multinationals: New players in the $21^{\text {st }}$ century globalization. Asia Pacific Journal of Management, 23(1): 5-27.

Mathur, A., \& Singh, K. 2007. Foreign direct investment, corruption and democracy. Working paper no. 135, American Enterprise Institute, Washington, DC.

McCalman, P. 2004. Foreign direct investment and intellectual property rights: Evidence from Hollyword's global distribution of movies and videos. Journal of International Economics, 62(1): 107-123.

Mayer, T. and Zignano, S. 2006. Notes on CEPII's distance measures. Available at http://www.cepii.fr/distance/noticedist_en.pdf.

Meyer, K.E., Estrin, S., Bhaumik, S.K., \& Peng, M. 2009. Institutions, resources, and entry strategies in emerging economies. Strategic Management Journal, 30(1): 61-80. 
Morck, R., Yeung, B., \& Zhao, M. 2008. Perspectives on China's outward foreign direct investment. Journal of International Business Studies, 39(3): 337-350.

Rauch, J.E. 1999. Network versus markets in international trade. Journal of International Economics, 48(1): 7-35.

Rosen, D.H. \& Hanemann, T. 2009. China's changing outbound foreign direct investment profile: Drivers and policy implication. Policy Brief PB09-14, Peterson Institute of International Economics, Washington, D.C.

Sauvant, K.P. 2005. New sources of FDI: the BRICs. Outward FDI from Brazil, Russia, India and China. Journal of World Investment and Trade, 6(5): 639-709.

Schulz, H. 2007. Political institutions and foreign direct investment in developing countries: Does the sector matter? Mimeo, University of Pennsylvania, Pittsburgh, http://www.polisci.upenn.edu/faculty/faculty-articles\&papers/Schulz_FDI.pdf.

Shatz, H., \& Venables, A. 2001. The geography of international investment, In G.L. Clark (Ed.), The Oxford handbook of economic geography: 125-145. New York: Oxford University Press.

Smith, P. 2001. How do foreign patent rights affect U.S. exports, affiliate sales, and licenses? Journal of International Economics, 55(2): 411-439.

Taylor, R. 2002. Globalization strategies of Chinese companies: Current developments and future prospects. Asian Business and Management, 1(2): 209-225.

Tinbergen, J. 1962. Shaping the world economy: Suggestions for an international economic policy. New York: The Twentieth Century Fund, Inc.

Tsai, K.S. 2002. Back-alley banking: Private entrepreneurs in China. Ithaca: Cornell University Press.

Walt, V. 2006. China's African Safari. Fortune, February 20, 41-44.

Walt, V. 2005. Iran Looks East. Fortune, February 21, 88-95.

Warner, M., Hong, N.S., \& Xu, X. 2004. Late development experience and the evolution of transnational firms in the People's Republic of China. Asia Pacific Business Review, 10(3-4): 324-345.

Wei, S-J. 2000. Why does China attract so little foreign direct investment? In T. Ito \& A. Krueger (Eds), The role of foreign direct investment in East Asian economic development: 239-265. Chicago: The University of Chicago Press.

Zhan, J.X. 1995. Transnationalization and outward investment: The case of Chinese firms. Transnational Corporations, 4(3): 67-100.

Zhang, Y. 2003. China's emerging global business: Political economy and institutional investigations. Basingstoke: Palgrave Macmillan.

Zhang, J. 2005. An exploratory study of bilateral FDI relations: The case of China. The Journal of Chinese Economic and Business Studies, 3(2): 133-150. 
Figure 1. China's economic cooperation related investment (2004-2006) and outward foreign direct investment (2006-2008), in natural log

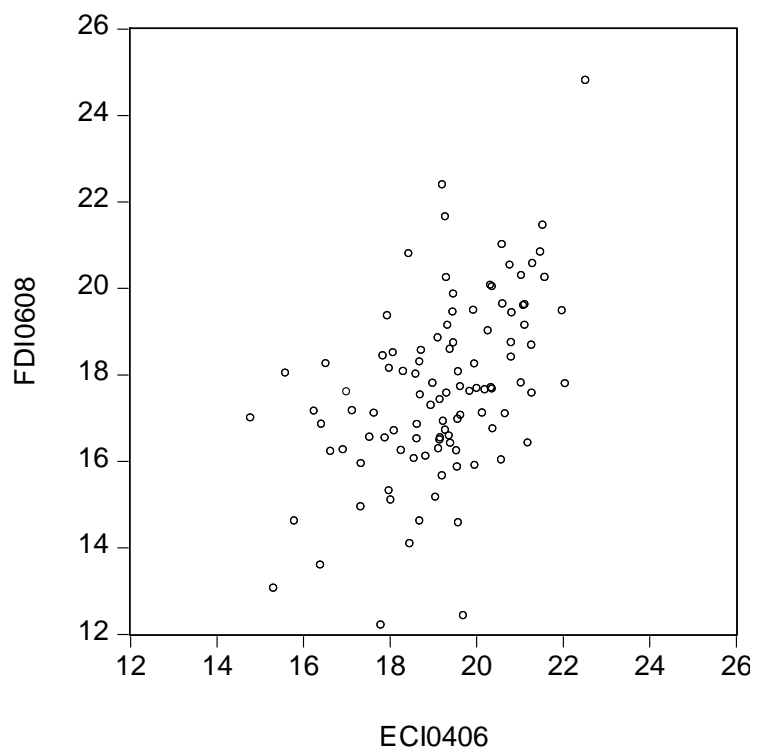

Note: Data for 104 countries are included here. A country is included if data for both economic cooperation investment (ECI) and outward foreign direct investment (FDI) are available for all relevant years and outward FDI is positive. 
Figure 2. Distribution of China's economic cooperation related investment (in natural log) 1998-2000 (left panel); 2001-2003 (middle panel); 2004-2006 (right panel)
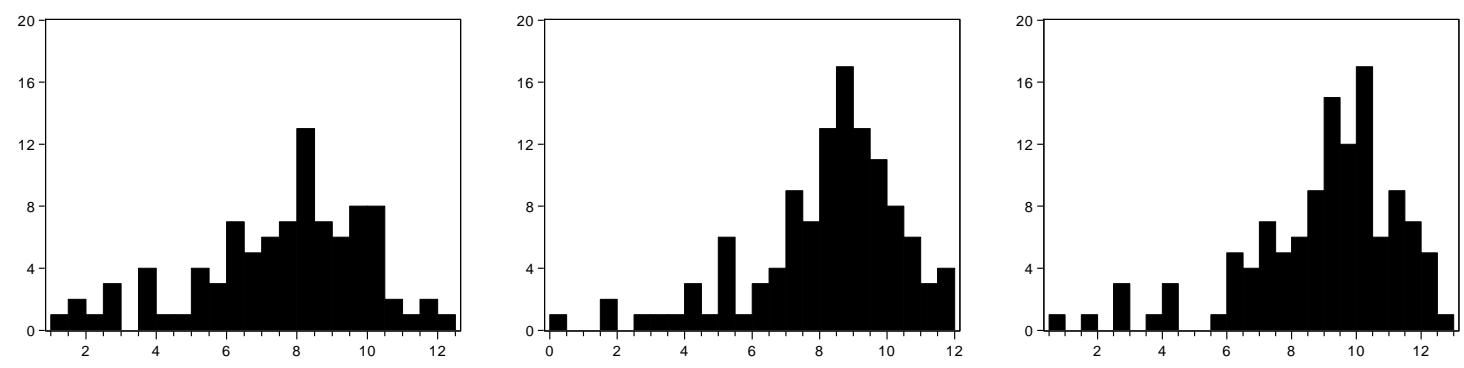
Figure 3. China's economic cooperation related investment (in natural log) against the share of energy (FUEL) and non-energy exports (MINERAL) to total exports, 1998-2000 (left panel); 2001-2003 (middle panel); 2004-2006 (right panel)
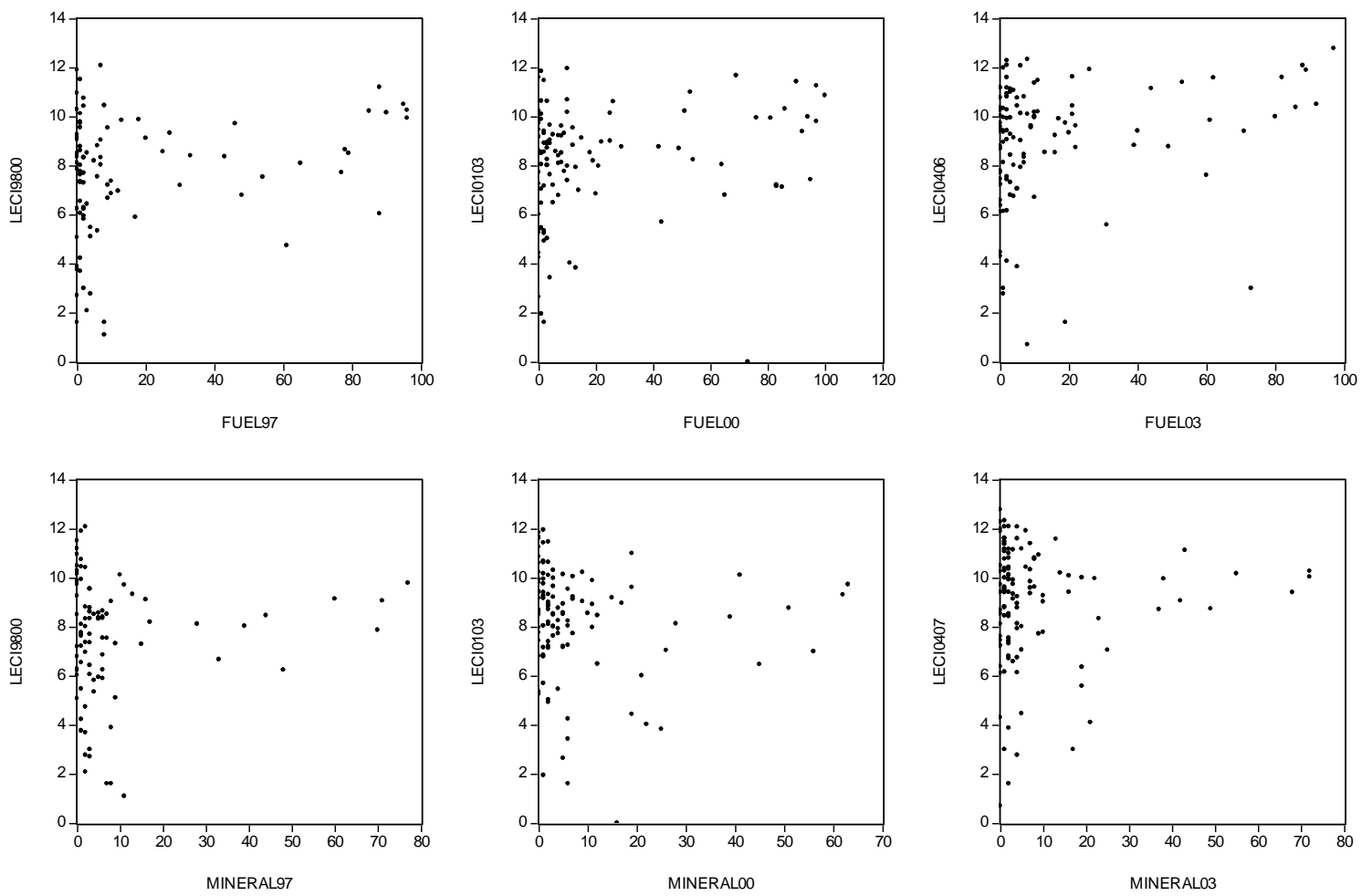
Figure 4. China's economic cooperation related investment (in natural $\log$ ) against freedom from corruption (CORRFREE) and political rights (POLRIGHT), 1998-2000 (left panel); 2001-2003 (middle panel); 2004-2006 (right panel)
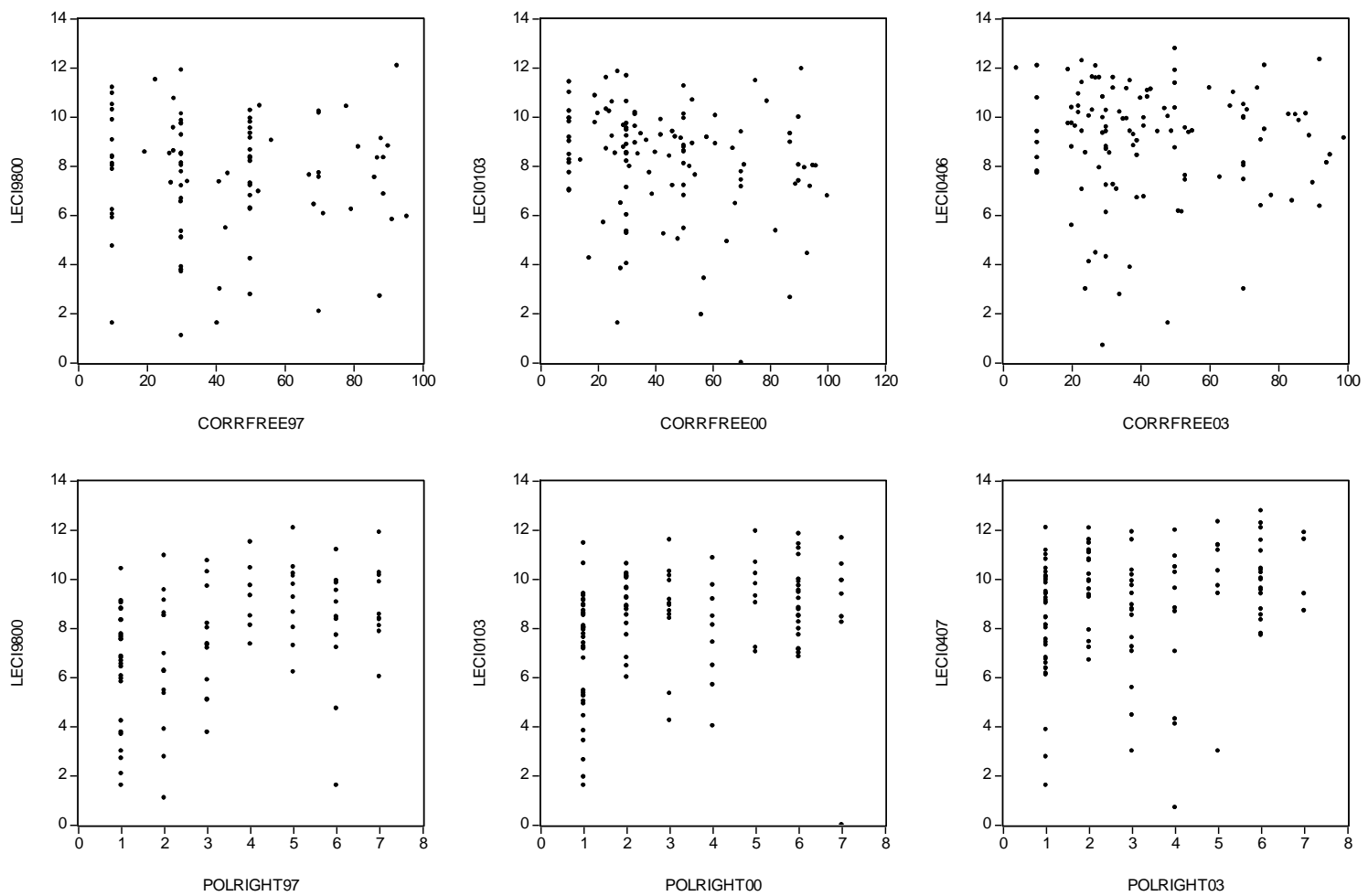

Notes: CORRFREE is an index from 0 to 100 with high values indicating low incidence of corruption; POLRIGH is an index ranging from 1 to 7 with 1 indicating the highest level of political freedom. 
Table 1. Descriptive statistics

\begin{tabular}{|c|c|c|c|c|c|c|c|c|c|}
\hline & 2004-2006 & & & 2001-2003 & & & $1998-2000$ & & \\
\hline Variable & Obs & Mean & Std. Dev. & Obs & Mean & Std. Dev. & Obs & Mean & Std. Dev. \\
\hline ECI & 118 & 353.61 & 564.83 & 115 & 156.73 & 279.31 & 92 & 123.25 & 277.07 \\
\hline GDP & 118 & 348 & $1,070.00$ & 115 & 329 & $1,010.00$ & 92 & 368 & $1,020.00$ \\
\hline GDPPC & 118 & $10,106.36$ & $9,579.95$ & 115 & $10,001.62$ & $10,259.20$ & 92 & $8,650.55$ & $8,834.63$ \\
\hline GEODIST & 118 & $8,960.99$ & $3,861.28$ & 115 & $8,881.66$ & $3,999.81$ & 92 & $9,125.90$ & $3,968.26$ \\
\hline EXPGROW & 118 & 2.11 & 2.64 & 115 & 2.36 & 2.07 & 92 & 1.47 & 3.15 \\
\hline INSTAB & 118 & 2.32 & 1.50 & 115 & 2.61 & 2.24 & 92 & 3.07 & 3.39 \\
\hline CULDIST & 118 & 0.02 & 0.13 & 115 & 0.02 & 0.13 & 92 & 0.02 & 0.15 \\
\hline BITRADE & 118 & $5,558.69$ & $18,212.42$ & 115 & $3,259.00$ & $10,963.18$ & 92 & $2,637.32$ & $8,502.16$ \\
\hline CORRFREE & 118 & 43.89 & 23.39 & 115 & 43.96 & 25.04 & 92 & 42.41 & 24.70 \\
\hline FUEL & 118 & 14.55 & 24.22 & 115 & 19.49 & 29.68 & 92 & 16.09 & 27.41 \\
\hline MINERAL & 118 & 8.13 & 14.55 & 115 & 7.56 & 12.86 & 92 & 8.36 & 15.90 \\
\hline POLRIGHT & 118 & 3.02 & 1.97 & 115 & 3.22 & 2.14 & 92 & 3.29 & 2.15 \\
\hline
\end{tabular}

Notes: ECI and BITRADE are in millions of US dollars. GDP (in billions) and GDPPC are in constant 2000 international (PPP) dollars. GEODIST is in kilometres. EXPGROW and INSTAB are both in percent form. Freedom from corruption (CORRFREE) is a proxy for institutional quality (INSTQLTY). Energy (FUEL) and non-energy minerals (MINERAL) are proxies for natural resources (NR). 
Table 2. Regression estimates (OLS - period average)

\begin{tabular}{|c|c|c|c|c|c|c|}
\hline & \multicolumn{3}{|c|}{ "Fuel" specification } & \multicolumn{3}{|c|}{ “Mineral” specification } \\
\hline & $\begin{array}{c}\text { 2004-06 } \\
(1) \\
\end{array}$ & $\begin{array}{c}\text { 2001-03 } \\
(2)\end{array}$ & $\begin{array}{c}\text { 1998-00 } \\
(3) \\
\end{array}$ & $\begin{array}{c}\text { 2004-06 } \\
(4)\end{array}$ & $\begin{array}{c}\text { 2001-03 } \\
(5) \\
\end{array}$ & $\begin{array}{c}\text { 1998-00 } \\
(6) \\
\end{array}$ \\
\hline Constant & $\begin{array}{l}8.91 * * \\
(3.96)\end{array}$ & $\begin{array}{l}9.31 * * * \\
(3.28)\end{array}$ & $\begin{array}{l}8.19 \\
(5.75)\end{array}$ & $\begin{array}{l}5.20 \\
(3.42)\end{array}$ & $\begin{array}{l}8.60 * * \\
(3.74)\end{array}$ & $\begin{array}{l}6.09 \\
(5.79)\end{array}$ \\
\hline$(\log )$ GDP & $\begin{array}{l}0.25 \\
(0.19)\end{array}$ & $\begin{array}{l}0.40^{* *} \\
(0.16)\end{array}$ & $\begin{array}{l}0.41 \\
(0.26)\end{array}$ & $\begin{array}{l}0.24 \\
(0.19)\end{array}$ & $\begin{array}{l}0.42 * * \\
(0.16)\end{array}$ & $\begin{array}{l}0.40 \\
(0.26)\end{array}$ \\
\hline (Log) GDP per capita & $\begin{array}{c}-1.20 * * * \\
(0.29)\end{array}$ & $\begin{array}{c}-1.10^{* * * *} \\
(0.28)\end{array}$ & $\begin{array}{c}-1.57 * * * \\
(0.37)\end{array}$ & $\begin{array}{c}-0.91 * * * \\
(0.29)\end{array}$ & $\begin{array}{c}-1.19 * * * \\
(0.31)\end{array}$ & $\begin{array}{c}-1.42^{* * *} \\
(0.36)\end{array}$ \\
\hline (Log) Distance & $\begin{array}{c}-0.33 \\
(0.35)\end{array}$ & $\begin{array}{c}-0.60 * * \\
(0.24)\end{array}$ & $\begin{array}{c}-0.34 \\
(0.47)\end{array}$ & $\begin{array}{c}-0.24 \\
(0.34)\end{array}$ & $\begin{array}{c}-0.44 \\
(0.29)\end{array}$ & $\begin{array}{l}-0.21 \\
(0.45)\end{array}$ \\
\hline Expected growth & $\begin{aligned} &- 0.01 \\
&(0.07)\end{aligned}$ & $\begin{array}{l}-0.11 \\
(0.09)\end{array}$ & $\begin{array}{l}0.12 * \\
(0.06)\end{array}$ & $\begin{array}{c}-0.02 \\
(0.08)\end{array}$ & $\begin{array}{l}-0.10 \\
(0.09)\end{array}$ & $\begin{array}{l}0.10 \\
(0.07)\end{array}$ \\
\hline Macro. volatility & $\begin{array}{r}-0.02 \\
(0.12)\end{array}$ & $\begin{array}{c}-0.09 \\
(0.09)\end{array}$ & $\begin{array}{l}-0.01 \\
(0.05)\end{array}$ & $\begin{array}{l}0.01 \\
(0.12)\end{array}$ & $\begin{array}{l}-0.06 \\
(0.10)\end{array}$ & $\begin{array}{c}-0.01 \\
(0.06)\end{array}$ \\
\hline Cultural distance & $\begin{array}{l}0.95 \\
(0.83)\end{array}$ & $\begin{array}{l}2.32^{* *} \\
(0.95)\end{array}$ & $\begin{array}{l}2.52 * * \\
(1.08)\end{array}$ & $\begin{array}{l}0.35 \\
(0.69)\end{array}$ & $\begin{array}{l}2.35 * * \\
(0.99)\end{array}$ & $\begin{array}{l}2.45 * * \\
(0.97)\end{array}$ \\
\hline (Log) bilateral trade & $\begin{array}{l}0.50 * * \\
(0.20)\end{array}$ & $\begin{array}{l}0.27 \\
(0.16)\end{array}$ & $\begin{array}{l}0.28 \\
(0.21)\end{array}$ & $\begin{array}{l}0.53^{* * *} \\
(0.20)\end{array}$ & $\begin{array}{l}0.28^{*} \\
(0.17)\end{array}$ & $\begin{array}{l}0.27 \\
(0.21)\end{array}$ \\
\hline Corruption free & $\begin{array}{l}0.03 * \\
(0.01)\end{array}$ & $\begin{array}{l}0.02 \\
(0.01)\end{array}$ & $\begin{array}{l}0.03^{*} \\
(0.01)\end{array}$ & $\begin{array}{l}0.02 * \\
(0.01)\end{array}$ & $\begin{array}{l}0.01 \\
(0.01)\end{array}$ & $\begin{array}{l}0.03 * \\
(0.01)\end{array}$ \\
\hline Fuel rich & $\begin{array}{l}0.03 \\
(0.03)\end{array}$ & $\begin{array}{l}0.04 * \\
(0.02)\end{array}$ & $\begin{array}{l}0.05 * * * \\
(0.02)\end{array}$ & - & - & - \\
\hline Mineral rich & - & - & - & $\begin{array}{l}0.09 * * \\
(0.05)\end{array}$ & $\begin{array}{l}0.02 \\
(0.12)\end{array}$ & $\begin{array}{l}0.03 \\
(0.04)\end{array}$ \\
\hline Political rights & $\begin{array}{l}0.16 \\
(0.13)\end{array}$ & $\begin{array}{l}0.21 \\
(0.14)\end{array}$ & $\begin{array}{l}0.32^{*} \\
(0.17)\end{array}$ & $\begin{array}{l}0.31^{* *} \\
(0.12)\end{array}$ & $\begin{array}{l}0.15 \\
(0.10)\end{array}$ & $\begin{array}{l}0.33^{* *} \\
(0.14)\end{array}$ \\
\hline $\begin{array}{l}\text { Fuel rich } \times \\
\text { Corruption free }\end{array}$ & $\begin{array}{r}-0.0003 \\
(0.0003)\end{array}$ & $\begin{array}{r}-0.0004 \\
(0.0003)\end{array}$ & $\begin{array}{l}0.0002 \\
(0.0003)\end{array}$ & - & - & - \\
\hline $\begin{array}{l}\text { Mineral rich } \times \\
\text { Corruption free }\end{array}$ & - & - & - & $\begin{array}{r}-0.0012 * \\
(0.0007)\end{array}$ & $\begin{array}{l}-0.0004 \\
(0.0015)\end{array}$ & $\begin{array}{c}-0.0002 \\
(0.0006)\end{array}$ \\
\hline $\begin{array}{l}\text { Fuel rich } \times \\
\text { Political rights }\end{array}$ & $\begin{array}{r}-0.0017 \\
(0.0039)\end{array}$ & $\begin{array}{r}-0.0047 \\
(0.0037)\end{array}$ & $\begin{array}{c}-0.0076^{* * * *} \\
(0.0029)\end{array}$ & - & - & - \\
\hline $\begin{array}{l}\text { Mineral rich } \times \\
\text { Political rights }\end{array}$ & - & - & - & $\begin{array}{r}-0.0096 * \\
(0.0056)\end{array}$ & $\begin{array}{r}-0.0034 \\
(0.0162)\end{array}$ & $\begin{array}{r}-0.0024 \\
(0.0056)\end{array}$ \\
\hline Observations & 118 & 115 & 92 & 118 & 115 & 92 \\
\hline R-squared & 0.41 & 0.48 & 0.48 & 0.41 & 0.46 & 0.44 \\
\hline F-statistic & $7.70 * * *$ & $7.73 * * *$ & $6.61 * * *$ & $7.62 * * *$ & $8.24 * * *$ & $6.60 * * *$ \\
\hline
\end{tabular}

Notes: The values within parentheses are robust standard errors. $\quad * * *, * *$ and $*$ indicate significance at the $1 \%, 5 \%$ and $10 \%$ levels, respectively. 
Table 3. Regression estimates (Random effects panel)

\begin{tabular}{|c|c|c|}
\hline & $\begin{array}{c}\text { "Fuel" } \\
\text { specification } \\
(1) \\
\end{array}$ & $\begin{array}{c}\text { "Mineral" } \\
\text { specification } \\
(2)\end{array}$ \\
\hline Constant & $\begin{array}{l}6.51 * \\
(3.80)\end{array}$ & $\begin{array}{l}4.75 \\
(3.85)\end{array}$ \\
\hline (Log) GDP & $\begin{array}{l}0.46 * * * \\
(0.16)\end{array}$ & $\begin{array}{l}0.45 * * * \\
(0.17)\end{array}$ \\
\hline (Log) GDP per capita & $\begin{array}{c}-1.35 * * * \\
(0.25)\end{array}$ & $\begin{array}{c}-1.25 * * * \\
(0.26)\end{array}$ \\
\hline (Log) Distance & $\begin{array}{r}-0.38 \\
(0.33)\end{array}$ & $\begin{array}{r}-0.28 \\
(0.33)\end{array}$ \\
\hline Expected growth & $\begin{array}{l}0.07 * \\
(0.04)\end{array}$ & $\begin{array}{l}0.07 \\
(0.04)\end{array}$ \\
\hline Macro. volatility & $\begin{array}{l}0.004 \\
(0.04)\end{array}$ & $\begin{array}{c}0.007 \\
(0.04)\end{array}$ \\
\hline Cultural distance & $\begin{array}{l}2.51 * * * \\
(0.86)\end{array}$ & $\begin{array}{l}2.36 * * * \\
(0.87)\end{array}$ \\
\hline (Log) bilateral trade & $\begin{array}{l}0.28 * * \\
(0.14)\end{array}$ & $\begin{array}{l}0.30 * * \\
(0.14)\end{array}$ \\
\hline Corruption free & $\begin{array}{l}0.02 * * \\
(0.01)\end{array}$ & $\begin{array}{l}0.01 \\
(0.01)\end{array}$ \\
\hline Fuel rich & $\begin{array}{l}0.03 * * \\
(0.02)\end{array}$ & - \\
\hline Mineral rich & - & $\begin{array}{l}0.02 \\
(0.03)\end{array}$ \\
\hline Political rights & $\begin{array}{l}0.11 \\
(0.10)\end{array}$ & $\begin{array}{l}0.16^{*} \\
(0.09)\end{array}$ \\
\hline $\begin{array}{l}\text { Fuel rich } \times \\
\text { Corruption free }\end{array}$ & $\begin{array}{r}-0.00003 \\
(0.0002)\end{array}$ & - \\
\hline $\begin{array}{l}\text { Mineral rich } \times \\
\text { Corruption free }\end{array}$ & - & $\begin{array}{r}-0.00001 \\
(0.0004)\end{array}$ \\
\hline $\begin{array}{l}\text { Fuel rich } \times \\
\text { Political rights }\end{array}$ & $\begin{array}{r}-0.00394 \\
(0.0027)\end{array}$ & - \\
\hline $\begin{array}{l}\text { Mineral rich } \times \\
\text { Political rights }\end{array}$ & - & $\begin{array}{r}-0.00424 \\
(0.0041)\end{array}$ \\
\hline Period dummies & Yes & Yes \\
\hline Observations & 325 & 325 \\
\hline Countries & 133 & 133 \\
\hline R-squared (within) & 0.42 & 0.42 \\
\hline R-squared (between) & 0.40 & 0.38 \\
\hline Wald $\chi^{2}$ statistic & $236.26 * * *$ & $233.75 * * *$ \\
\hline Breusch-Pagan LM $\chi^{2}$ statistic & $30.35 * * *$ & $34.43 * * *$ \\
\hline
\end{tabular}

Notes: The values within parentheses are robust standard errors.

$* * *, * *$ and $*$ indicate significance at the $1 \%, 5 \%$ and $10 \%$ levels, respectively. 